\title{
特集『都市再生と環境配慮』にあたって Urban Revitalization and Environmental Quality
}

\author{
Sachihiko HARASHINA
}

都市再生とは何か。政府は 6 月 1 日に施行された都市再生特別措置法により, 緊急整備地域を全国 で17箇所制定した。だが，単に高度利用を図るだけでは，再開発により近代的なビル街はできても都 市再生につながるかは疑わしい。

都市再生とは，単に高層建築物を作ることではない。魅力的な都市空間を作り，生産活動と共に多 様な人々が住み生活してこそ，都市再生がなされる。政府の計画には都市づくりの哲学が見えない。 今進められているのは再開発を容易にするだけの方策であり, 強引な計画の実施は, 地区の歴史文化 の破壊と居住環境の悪化をもたらす。都市計画上の規制の撤廃は, 都市づくりの哲学は不用だという に等しい。

心配なのは環境配慮にも消極的なことである。今日, 環境保全は魅力的な都市の必須条件であり, アセスはそのための重要な手段である。だが, 例えば, 東京都は 7 月に環境影響評価条例を改正し, 都市再生を推進する都心の一部地区で高層建築物のアセス対象要件を大幅に緩和した。これでは良好 な都市環境の形成は望めない。都のアセス緩和は都市環境の悪化を招く恐れが大である。

事業アセスだけでは不充分だが，それでもアセスがあることにより，事業者は環境配慮した事業計 画を行う。アセスがなければ最小限の対応しか期待できず, 魅力的な都市空間が創造される可能性は 低い。都のこれまでの $10 \mathrm{ha}$ 以上かつ $100 \mathrm{~m}$ 以上という規模設定自体が緩すぎたが, 今回, $15 \mathrm{ha}$ 超かつ $180 \mathrm{~m}$ 超まで緩和されたため, ほとんどの開発行為はアセス対象ではなくなる。条件緩和により事業 アセスの対象にもならなければ適切な環境配慮が望めず, 都市再生には逆行する結果となる。

東京は既に超過密都市である。しかし, 昨今の都市再生議論を聞くと, どれだけの人がこの事実を 明確に認識しているか疑問である。現在, 東京23区のオフィス床面積は8000ha以上で, これはニュー ヨーク市全体 $3800 \mathrm{ha}$ の 2 倍以上にもなる。ニューヨーク市の市域面積は23区より広いが，オフィス 総床面積は東京の半分以下しかない。1980年頃には両者のオフィス床面積はほぼ同等だったが，バブ ル以降の 20 年間に東京は倍増した。オフィスがこれだけ供給過剰になったのだから, 2003年問題が心 配されるはずである。

都のアセス条例改正では, 総合計画や上位計画を対象とする計画アセスの部分的な導入を行ったが, 肝心の民間開発は対象外とした。その結果, 超過密都市東京の密度を下げ, 災害リスクを減少させる 機会を逸してしまった。事業段階のアセスで容積が大幅に減ることはほとんどない。根本的には地域 の容積設定を見直せるよう, 事業より前の計画段階でのアセスが必要である。だが，この根本的な改 正は見送られた。

高層建築物を建てやすくするだけでは, ヒートアイランド現象などの環境悪化を招き, 都市再生で なく都市の死滅に至る。目先の経済優先は, むしろ経済の停滞を招くこととなる。しかもこの場合は, ご く一部の企業の利益を生むのものでしかなく，産業構造を変えることによる真の経済活性化ではない。

環境配慮を軽んずる不動産開発では都市再生にはならない。都市再生のためには, むしろアセス対 象を拡大し, 計画アセスも導入するべきである。アセスを正しく行い開発計画を十分に環境配慮した 魅力的なものとし，真の都市再生をしなければならない。 